\title{
Attempts to Induce Tumours with Nucleic Acid Preparations from Agrobacterium tumefaciens
}

\author{
By R. PHILLIPS \\ Department of Botany and Microbiology, University College, London WCI E 6BT \\ AND D. N. BUTCHER \\ A.R.C. Unit of Developmental Botany, Cambridge $C B_{3} \circ D Y$
}

(Received 28 August 1974)

\begin{abstract}
SUMMARY
Nucleic acid preparations from Agrobacterium tumefaciens (Smith \& Townsend) Conn. have been tested for tumorigenic activity on a number of bioassay systems including carrot root explants, sunflower and tobacco stem segments, callus cultures of sunflower, tobacco and carrot, and sunflower stems. The methods used to isolate and test the DNA included those which have been reported to be successful for the induction of tumours. Strict precautions were taken to ensure that the DNA samples used in the tests were free of viable bacterial cells. In the large number of tests carried out under various experimental conditions there was no evidence for the induction of tumours with bacterial DNA.
\end{abstract}

\section{INTRODUCTION}

Tumours may be induced on a wide range of higher plant species by inoculating wounded tissues with Agrobacterium tumefaciens (Smith \& Townsend) Conn. Once initiated, such tumours no longer require the presence of the bacterium for continuous abnormal growth. There have been many attempts to discover the nature of the bacterial factors which are responsible for the tumour induction and there are a number of recent reports that nucleic acid preparations from $A$. tumefaciens, or from a phage isolated from it, may induce tumours (Kovoor, 1967; Leff \& Beardsley, 1970; Beltrá \& Rodriguez, I97I; Kado, Heskett \& Langley, I972; Swain \& Rier, 1972). If correct, these findings are important since they suggest that genetic information from bacteria may be transferred to and persist in the host cells and thereby cause tumorous growth. Unfortunately these reports have been of a preliminary nature and either failed to establish that the nucleic acid preparations were free of viable cells of $A$. tumefaciens or that the overgrowths induced were true tumours. To establish the latter, we consider it essential to determine that the disorganized growth continues indefinitely in culture in the absence of the causal agent (nucleic acids) on an auxinand cytokinin-free medium (autonomy for auxins and cytokinins is a characteristic of cultured crown-gall cells), and that the overgrowths can give rise to continuously growing tumours when grafted on to healthy plants of the same species. Using these criteria as evidence for tumour induction we have attempted to induce tumours in a number of plant tissues with various types of nucleic acid preparation under a wide range of experimental conditions. 


\section{METHODS}

Extraction of nucleic acids from bacteria. Agrobacterium tumefaciens strain B6 was cultured in a medium containing $(\mathrm{g} / \mathrm{l})$ nutrient broth (Oxoid $\mathrm{CM} \mathrm{I}$ ), 8; yeast extract (Oxoid L2I), I; sucrose, 20; $\mathrm{KH}_{2} \mathrm{PO}_{4}, 3 ; \mathrm{MgSO}_{4} \cdot 7 \mathrm{H}_{2} \mathrm{O}, 0 \cdot 3 ; \mathrm{pH} 7 \cdot 0$. Bacteria were used for tumour induction or harvested for preparing nucleic acids after 16 to $18 \mathrm{~h}$ when the cultures were still in a logarithmic growth phase.

Purified DNA was prepared either by the method of Marmur (I96I) or by the phenol method developed by Schilperoort (1969). The latter method was used in most experiments and the procedure was as follows. The bacteria were lysed by sodium dodecyl sulphate in the presence of pronase and the resulting extract was repeatedly deproteinized with phenol followed by treatment with ribonuclease and then pronase. Finally the DNA preparation was deproteinized again with phenol and precipitated with cold ethanol. Typical ratios of u.v. absorption for this DNA were 0.432: I $\cdot 000: 0 \cdot 53 \mathrm{I}$ for wavelengths 230,260 and $280 \mathrm{~nm}$, respectively. Caesium chloride density gradient centrifugation gave a single peak. The molecular weight of a sample that had been repeatedly reprecipitated and redissolved was found to be $6.9 \times 10^{6}$ on sucrose density centrifugation. This probably represents a minimum value.

Less highly purified preparations were also used, including a mixture of RNA and DNA obtained by omitting the ribonuclease treatment, and a crude bacterial lysate containing nucleic acids, proteins and polysaccharides. All preparations were sterilized with $70 \%$ ethanol and stored at $-15{ }^{\circ} \mathrm{C}$ under $70 \%$ ethanol. Before use they were dissolved in sterilized saline citrate buffer (O. I5 M-NaCl, 0.0I5 M-trisodium citrate, $\mathrm{pH} 7 \cdot 3)$. Sterility of the final solution was routinely checked by plating on to a medium suitable for the growth of A. tumefaciens.

Tests for tumour-inducing properties. (i) Carrot root explants. Discs $6 \mathrm{~mm}$ in diameter and 2 to $3 \mathrm{~mm}$ thick from the roots of Daucus carota cultivar Chantenay were cut under aseptic conditions so as to include tissues of secondary phloem, cambium and xylem. The discs were cultured on an agar $(0.7 \%$, w/v) solidified medium containing modified White's root culture medium (Street \& Henshaw, I966) supplemented with $(\mathrm{mg} / \mathrm{l}): \mathrm{KCl}, 845 ; \mathrm{NaNO}_{3}$, I $800 ; \mathrm{NaH}_{2} \mathrm{PO}_{4} . \mathrm{H}_{2} \mathrm{O}, 300 ;\left(\mathrm{NH}_{4}\right)_{2} \mathrm{SO}_{4}, 790$ (Braun \& Wood, I962). After incubation for $\mathrm{I} 8 \mathrm{~h}$ on this basic medium each disc was treated with $20 \mu \mathrm{l}$ of either a nucleic acid solution, saline citrate buffer or a suspension of $A$. tumefaciens strain B6. The treated discs were incubated at $25^{\circ} \mathrm{C}$ and examined periodically for overgrowths.

(ii) Sunflower seedlings. Seedlings of Helianthus annuus cultivar Russian Giant were grown in compost (John Innes No. 2) in a glasshouse. Plants $45 \mathrm{~cm}$ in height were wounded by passing a sterilized needle through the stem of the youngest fully expanded internode. The wound was covered with a moist sterilized bandage to prevent contamination by microorganisms and drying out. After $48 \mathrm{~h}$ the bandage was temporarily removed to introduce the test solutions i.e. $50 \mu \mathrm{l}$ of nucleic acid solution, citrate buffer (control) or a bacterial suspension. The bandage was finally removed three days after inoculation.

(iii) Callus cultures. Established callus cultures of $H$. annuus cultivar Russian Giant, Daucus carota cultivar Chantenay and Nicotiana rustica were grown on the basic medium (see above) supplemented with (mg/l) dichlorophenoxyacetic acid (2,4-D), 0.15 ; kinetin, 0.5 ; meso-inositol, I0o. The replicates of each isolate were treated with DNA as described by Kovoor (1967). A small cavity was made in each rapidly growing callus with a scalpel and pieces of DNA (about $3 \mathrm{mg}$ ) prepared by the Marmur (I96I) method were inserted. The cavities were finally plugged with callus tissue. The treated calluses were cultured on the 
auxin- and kinetin-supplemented medium for a further two weeks before being transferred to the unsupplemented medium.

(iv) Internode segments of tobacco. Segments 5 to $10 \mathrm{~mm}$ in length were cut from the youngest fully-expanded internodes of six-week-old plants of Nicotiana tabacum cultivar Wisconsin 38, sterilized, and incubated on basic medium. The segments were treated at the appropriate time $(0,18$ or $48 \mathrm{~h})$ after excision by applying a $20 \mu \mathrm{l}$ drop of nucleic acid solution, sodium citrate buffer or a suspension of bacteria to the upper cut surface of the segment. This was followed by making $\mathrm{I} 2$ wounds in the cortex with a sterilized needle. The $25 \mathrm{ml}$ flasks containing the segments were incubated at $25^{\circ} \mathrm{C}$ at low light intensities.

(v) Sunflower hypocotyl segments. Sunflower seeds were germinated in the dark at $25^{\circ} \mathrm{C}$ in Petri dishes containing moist filter papers. When the hypocotyls were 10 to $15 \mathrm{~cm}$ long they were surface sterilized, cut into $3 \mathrm{~mm}$ segments and transferred to flasks containing basic medium and incubated for $\mathrm{I} 8 \mathrm{~h}$. They were then removed and treated with bacterial nucleic acid either by the application of $20 \mu \mathrm{l}$ drops to the cut surface or by total immersion in nucleic acid solution for $24 \mathrm{~h}$. The segments were then returned to the basic medium.

(vi) Continuous application of DNA by glass capillaries. Segments $(3 \mathrm{~cm})$ of Nicotiana tabacum internodes or cylinders $(3 \mathrm{~cm}$ long, $0.6 \mathrm{~cm}$ diam) of carrot root were supported in an upright position by pushing them into an agar medium. A fine glass capillary with an upper reservoir capable of holding about $0.25 \mathrm{ml}$ fluid was then inserted into the explants and filled with DNA solution, which was replenished daily to provide a continuous supply of DNA to the tissues.

DNase activity of carrot root explants. Since the carrot-disc bioassay was the most extensively used for tumorigenicity tests it was considered advisable to check the capacity of such discs to degrade exogenously added DNA. The DNA solution of $A$. tumefaciens used as substrate was prepared so as to contain $400 \mathrm{mg}$ phenol-purified DNA/IO $\mathrm{ml}$ of $\mathrm{O} \cdot \mathrm{I}$ Macetate buffer and $0.05 \mathrm{M}-\mathrm{MgSO}_{4} \mathrm{pH} 5^{\circ}$. Twenty carrot discs, either freshly cut or maintained for $\mathrm{I} 8 \mathrm{~h}$ on the basic culture medium, were incubated for $\mathrm{I} 5 \mathrm{~h}$ at $25^{\circ} \mathrm{C}$ with $\mathrm{Io} \mathrm{ml}$ substrate. The undegraded DNA remaining in the supernatant was determined as follows: an aqueous solution $(0.5 \mathrm{ml})$ containing $50 \mu \mathrm{g}$ DNase I (Sigma) was added to $2.5 \mathrm{ml}$ of the supernatant. After mixing, the increase in u.v. absorption at $260 \mathrm{~nm}$ was measured until a maximum was reached. This increase was compared with control solutions and the amounts of DNA degraded were estimated. The results indicated relatively low levels of DNase activity, there being 12.7 and $10.5 \mu \mathrm{g}$ DNA degraded per disc by the freshly-cut and pre-incubated discs, respectively, after $15 \mathrm{~h}$. This represented about $25 \%$ of the DNA ( $40 \mu \mathrm{g}$ in a $20 \mu \mathrm{ldrop}$ ) added to the discs in the tumorigenicity tests. This is probably an over estimate of the degradation during the tests since the bacterial DNA was applied only to the upper surface of the discs. It was concluded that a large proportion of the DNA survived for a considerable period. However it was realized that the experiment did not rule out the possibility that the applied DNA was rapidly degraded to large fragments which were not detectable by the analysis or absorbed by the discs. Nor did it indicate the location of the DNase activity and it was possible that the DNA was degraded before entering the cells.

\section{RESULTS}

Generally, we have concentrated on attempts to repeat some of the positive reports of tumour induction by DNA preparations from $A$. tumefaciens. However, when such attempts failed we extended the tests to include other treatments which might have been expected to facilitate tumour induction. 


\section{Experiments with carrot root explants}

Our chief experimental material was the carrot root explant which included secondary phloem, cambium and xylem. The advantages of this test were that a large number of replicates could be used and the material was easily kept under aseptic conditions. It also enabled us to test whether any overgrowths induced by our treatments were capable of continuous growth in the absence of the causal agent and plant hormones. A further advantage was that tumours could be consistently induced on discs within I4 days by applying a suspension of $A$. tumefaciens to the cut surface. Using a similar system in nonsterile conditions, Beltrá \& Rodriguez (197I) claimed to have induced crown gall tumours with DNA prepared from $A$. tumefaciens.

Attempts to induce tumours with phenol-purified DNA. Carrot root discs were preincubated for $48 \mathrm{~h}$ on the basic culture medium to satisfy the wound requirement, and then divided into three groups of 210 discs. Each disc was treated by applying a $20 \mu 1$ drop of the appropriate solution to the upper surface. The treatments included (i) saline citrate buffer (control), (ii) a solution of DNA prepared by the phenol method and (iii) a suspension of $A$. tumefaciens. Of the bacterium-treated discs more than $90 \%$ developed small tumours within Io days. These tumours were chiefly located over the cambium and phloem and were white or pale green in colour. They were initially spherical and isolated, but later fused to form large irregularly-shaped masses. The growth of the tumour tissues continued for about 3 weeks, but eventually succumbed to massive bacterial overgrowth. In contrast none of the DNA- or saline citrate-treated discs developed overgrowths comparable to those induced by the bacterium. There was a slow development of a whitish wound callus, but this did not persist and the discs soon showed necrosis. In order to avoid the possibility that toxic substances from the original explant were responsible for the cessation of growth, the wound callus was sliced from the surface of the discs with a scalpel at an early stage and transferred to fresh medium lacking auxin and cytokinin. No further growth was observed and the tissues eventually showed necrosis. This experiment was repeated three times with identical results. There was no evidence that our DNA preparations had tumorigenic properties.

Although the wound conditioning period used above was suitable for the induction of tumours by the bacterium, it was thought possible that this critical period might be different for the induction of tumours by DNA preparations. Thus, DNA was applied o, I8, 42 and $66 \mathrm{~h}$ after excision of the carrot discs. In another experiment $20 \mu \mathrm{l}$ of phenol-purified DNA were added daily to the discs to reduce the possibility that the DNA was degraded and therefore rendered ineffective. Neither experiment provided any evidence that tumours were induced by the DNA.

Following the report of Heyn \& Schilperoort (1973) that DEAE-dextran enhances adsorption and penetration of DNA in tobacco cells, DEAE-dextran was tested as a possible co-factor for tumour induction by DNA. Carrot discs were either pre-incubated in a solution of DEAE-dextran $(50 \mu \mathrm{g} / \mathrm{ml})$ for $30 \mathrm{~min}$ before the application of phenol-purified DNA, or DEAE-dextran (20 to $50 \mu \mathrm{g} / \mathrm{ml}$ ) was incorporated into the DNA solutions (phenol or Marmur methods). Neither treatment caused tumour-like overgrowths to develop on the discs.

Attempts to use plant hormones as co-factors for tumour induction by DNA. In several reports on crown gall it has been suggested that plant hormones, particularly auxins and cytokinins, may be important co-factors in the induction of tumours (see Butcher, 1973). Therefore a number of experiments were done in which carrot discs were treated with 
DNA in the presence of auxin and kinetin. Freshly cut discs were placed on the basic medium supplemented with (mg/l): 2,4-D, 0.15 ; kinetin, 0.5 ; meso-inositol, I00. A drop (20 $\mu \mathrm{l})$ of either DNA or saline citrate (control) was applied after 18 or $42 \mathrm{~h}$. The discs were transferred to a hormone-omitted medium immediately or after I, 3 or 7 days. In all treatments, including controls, rapid cell proliferation was observed after one week, resulting in fastgrowing callus tissues. Pieces of callus from each treatment were subcultured on to a hormone-omitted medium where they grew rapidly for at least one month. Subsequently, however, growth rates declined and organogenesis was observed. After 3 months, cultures of DNA-treated and control cultures were composed entirely of small plantlets, indicating that the initial proliferations were the result of carry-over of auxin from the original explants.

Attempts to induce tumours with other bacterial preparations. Having failed to induce tumours with phenol-purified DNA preparations, other cell-free extracts from A. tumefaciens were tested. Thirty replicate discs were used for each treatment and observations were made at intervals for a minimum period of 3 months when necrosis was evident. The treatments were (i) phenol-purified DNA; (ii) a mixture of DNA and 'RNA; (iii) bacterial lysate which included nucleic acids, proteins and polysaccharides; and (iv) filtered culture medium in which $A$. tumefaciens had been grown. None of the treatments caused overgrowths comparable to those induced by the bacterium or which grew indefinitely on a hormone-omitted medium.

\section{Attempts to induce tumours on other tissues}

Sunflower stems. The inoculation of wounded stems (youngest expanded internode) with a suspension of $A$. tumefaciens results in a rapidly growing tumour within Io to 12 days. In two experiments involving 20 plants, phenol-purified bacterial DNA failed to cause tumours to be formed. Even after 7 weeks the DNA-treated plants could not be distinguished from the saline citrate-treated controls.

Tissue cultures. Kovoor (1967) reported that the treatment of callus cultures of Scorzonera hispanica with large amounts of DNA from A. tumefaciens induced tumour-like tissues. We attempted similar experiments with tissue cultures of Nicotiana rustica, Daucus carota and Helianthus annuus. Twenty callus cultures of each species were treated with precipitated DNA ( $3 \mathrm{mg})$ and transferred to a hormone-free medium. The callus cultures of tobacco and sunflower continued to grow for 2 weeks, but then became brown and necrotic. The carrot cultures, however, continued to grow vigorously for 4 weeks and were subcultured on to fresh hormone-free medium. The growth rate was maintained for a further 3 to 4 weeks but it eventually declined giving way to shoots and roots. With all three species the DNAtreated callus tissues behaved in an identical manner to the control cultures. It was presumed that the limited growth on hormone-free media resulted from a carry-over of auxin from the previous auxin-supplemented medium.

Further tests for tumour-inducing activity of DNA on internode segments of tobacco, hypocotyl segments of sunflower and carrot root explants. Tobacco internode segments were treated with bacterial DNA or bacteria at various times after placing on an auxinfree medium. In a second experiment DNA-treated segments were wounded daily for 5 days. No tumour-like growths developed during 7 weeks, while segments treated with the bacteria all developed rapidly growing proliferations.

Another series of experiments involved the use of sunflower hypocotyl segments. Segments were treated either by the application of a drop of DNA solution to the cut surfaces or by the total immersion of segments in the DNA solution. A variety of treatments were 
employed including the use of DEAE dextran, different wound conditioning periods and auxins as co-factors. Only those segments which were exposed to auxin proliferated and even then the growth ceased when the segments were transferred to an auxin-free medium.

Finally, cylindrical carrot phloem explants and tobacco internode segments were supplied continuously with a DNA solution by means of glass capillary tubes inserted into the centre of the explants. Over a period of I I weeks considerable swelling of the carrot tissues occurred and there was appreciable development of leafy shoots on the tobacco segments. These features, however, were also observed on the controls where saline citrate was supplied.

\section{DISCUSSION}

Nucleic acid preparations from $A$. tumefaciens were examined for tumorigenic activity with carrot root explants as the principal test system. DNA samples prepared by several different methods were tested over a wide range of conditions, but on no occasion was there any evidence for the induction of tumorous tissues. These results were contrary to those of Beltrá \& Rodriguez (I97I) who reported that treatment of carrot explants with DNA from $A$. tumefaciens strain B6 caused overgrowths comparable to tumours induced by viable bacteria. They claimed that the induced overgrowths were capable of proliferating indefinitely on culture media devoid of plant hormones. Their work can be criticized on two important points. Firstly, there is doubt as to the sterility of their DNA solutions and of the carrot explants tested; we do not consider that the inclusion of antibiotics in the DNA solution eliminates the possibility that their overgrowths were caused by viable bacteria. Secondly, it is not possible to judge whether the overgrowths referred to as tumours were still actually growing at the end of Beltrá \& Rodriguez' experimental period of 62 days. We have tested conditions very similar to the ones they used without observing overgrowths in any way comparable to the tumours induced by $A$. tumefaciens.

Our attempts to confer tumorous properties to callus tissues of sunflower, tobacco and carrot with bacterial DNA preparations were unsuccessful. This contrasts with the report by Kovoor ( 1967 ) that relatively large amounts of DNA isolated from $A$. tumefaciens induced tumorous properties to callus cultures of Scorzonera hispanica. It was claimed by Kovoor that 1 out of 18 treated calluses in one experiment and 4 out of 48 in another became auxin-independent. However, it is known that callus cultures from this species occasionally give rise spontaneously to habituated tissues which are capable of growing indefinitely on auxin-omitted media (Gautheret, 1948). Hence it is possible that the small number of auxinindependent cultures isolated represented habituated tissues.

Kado et al. (1972) observed overgrowths resembling crown galls on wounded sunflower stems after treating with high molecular weight DNA preparations from A. tumefaciens strain IDI35. However, tumours could not be induced at will and no attempts were made to verify the tumorous nature of the growths by culturing on an auxin-omitted medium. Also, the tests were not carried out under strict aseptic conditions and therefore did not exclude the possibility of bacterial contamination. Our attempts to repeat this work, by treating sunflower stems with uncontaminated DNA, failed. The claims that tumour-like overgrowths have been induced by bacterial DNA on Phaseolus stems are open to the same criticism (Beltrá \& Rodriguez, 1971). There are similar doubts about the report by Swain \& Rier (I972) that RNA preparations from $A$. tumefaciens injected into tobacco stems caused tumorous growths, since their experiments were not replicated or carried out under aseptic conditions. Kado et al. (1972) could not induce tumours on sunflower stems with mRNA, 
rRNA or tRNA. Similarly, our preparations containing mixtures of RNA and DNA failed to induce tumours on carrot explants.

Leff \& Beardsley (1970) reported that DNA prepared from phage PS8 (originally isolated from crown-gall tumour tissue cultures and propagated on a phage-sensitive strain of A. tumefaciens) caused tumours to develop on various plant tissues. However, recent careful attempts to repeat this work with the co-operation of one of the original authors failed to corroborate this claim (Beiderbeck, Heberlein \& Lippincott, I973).

Beljanski et al. (1974) report the induction of tumours by specific low-molecular-weight RNA fractions; however, the overgrowths could not be maintained on an auxin-omitted medium, and the test plants were raised on a medium containing auxin and cytokinin.

The presence of DNA plasmids in virulent strains of $A$. tumefaciens has been reported by Zaenen et al. (1974), while similar plasmids were not detected in several non-virulent strains. However, such plasmids would probably have been lost from the DNA preparations used in our study. The significance of such plasmids in crown-gall inception remains to be elucidated.

One of us (R.P.) was supported by a Science Research Council Fellowship during the course of this work. We thank Professor P. W. Brian for encouragement and facilities, and $\mathrm{Mr}$ A. Sogeke for advice and assistance.

\section{REFERENCES}

Beiderbeck, R., Heberlein, G. T. \& Lippincott, J. A. (1973). On the question of crown-gall tumor initiation by DNA of bacteriophage PS8. Journal of Virology II, 345-350.

Beljanski, M., Aaron-Da Cunha, I., Beljanski, M. S., Manigault, P. \& Bourgarel, P. (I974). Isolation of the tumour-inducing RNA from oncogenic and non-oncogenic Agrobacterium tumefaciens. Proceedings of the National Academy of Sciences of the United States of America 71, I585-I589.

BeLtrá, R. \& Rodriguez, D. L. (I97I). Aseptic induction of the crown-gall tumours by the nucleic acid fraction from Agrobacterium tumefaciens. Phytopathologische Zeitschrift 7o, 35I-358.

Braun, A. C. \& WoOD, H. N. (1962). On the activation of certain essential biosynthetic systems in cells of Vinca rosea L. Proceedings of the National Academy of Sciences of the United States of America 48, $1776-1782$.

BUtCHER, D. N. (1973). The origins, characteristics and culture of plant tumour cells. In Plant Tissue and Cell Culture, pp. 356-39I. Edited by H. E. Street. Oxford: Blackwell.

Gautheret, R. G. (1948). Sur la culture de trois types de tissus de Scorzonère: tissus normaux, tissus de crown-gall et tissus accoutumés à l'hetero-auxin. Comptes rendus hebdomadaires des séances de l'Académie des sciences $D$ 226, 270-27I.

Heyn, R. F. \& SCHILPEROORT, R. A. (1973). The use of protoplasts to follow the fate of Agrobacterium tumefaciens DNA on incubation with tobacco cells. In Protoplasts et Fusion de Celles somatiques végetales. Colloques Internationaux du Centre National de la Recherche Scientifique No. 2I 2, pp. 385-395. Paris.

Kado, C. I., Heskett, M. G. \& LANGLey, R. A. (1972). Studies on Agrobacterium tumefaciens: characterisation of strains ID 135 and $\mathrm{B} 6$ and analysis of the bacterial chromosome, transfer RNA and ribosomes for tumour-inducing ability. Physiological Plant Pathology 2, 47-57.

Kovoor, A. (1967). Sur la transformation de tissus normaux de Scorzonère provoquée in vitro par l'acide désoxyribonucleique d'Agrobacterium tumefaciens. Comptes rendus hebdomadaires des séances de l'Académie des sciences $D$ 265, $1623-1626$.

LeFF, J. \& Beardsley, R. E. (1970). Action tumorigene de l'acide nucleique d'un bactériophage present dans les culures de tissu tumoral de Tournesal (Helianthus annuus). Comptes rendus hebdomadaires des séances de l'Académie des sciences $D$ 270, 2505-2507.

MARMUR, J. (I96I). A procedure for the isolation of deoxyribonucleic acid from micro-organisms. Journal of Molecular Biology 3, 208-2 I8.

SCHILPEROORT, R. A. (1969). Investigations on plant tumors-crown gall. Thesis, University of Leiden, The Netherlands. 
Street, H. E. \& Henshaw, G. G. (1966). Introduction and methods employed in plant tissue culture. In The Biology of Cells and Tissues in Culture, vol. 3, pp. 459-532. Edited by E. N. Willmer. New York: Academic Press.

SwaIN, L. W. \& RIER, J. P. (1972). Cellular transformation in plant tissue by RNA from Agrobacterium tumefaciens. Botanical Gazette 133, 318-324.

Zaenen, I., Van Larebeke, N., Teuchy, H., Van Montagu, M. \& Schell, J. (1974). Supercoiled circular DNA in crown gall inducing Agrobacterium strains. Journal of Molecular Biology 86, I09-127. 